\title{
ARSITEKTUR TRADISIONAL TIONGHOA: Tinjauan Terhadap Identitas, Karakter Budaya dan Eksistensinya
}

\author{
Hamdil Khaliesh \\ Program Studi Arsitektur, Fakultas Teknik Universitas Tanjungpura, Indonesia \\ hamdiel_st@yahoo.com
}

\begin{abstract}
ABSTRAK
Budaya merupakan sebuah proses perkembangan pola pikir yang terjadi secara bertahap dalam waktu yang lama. Proses ini terjadi selama manusia ada dan terus berkembang sesuai dengan pengembangan wawasan keilmuan. Setting lingkungan merupakan salah satu faktor yang berperan kuat dalam pembentukan karakter budaya. Tionghoa merupakan etnis yang banyak melakukan perpindahan ke daerah lain termasuk diantaranya daerah barat dan asia, baik dengan hubungan perdagangan maupun ekspedisi. Saat ini, banyak ditemukan daerah Permukiman Tionghoa di beberapa tempat, sebut saja Pecinan atau China town. Namun yang menarik adalah perbedaan tempat dan lingkungan tersebut tidak membuat eksistensi Budaya Tionghoa memudar. Dari sekian banyak karakter budaya Tionghoa, yang paling menonjol adalah bentuk arsitekturnya. Hal ini terjadi karena bentuk budaya yang paling mudah dilihat adalah bentuk fisiknya dalam hal ini arsitektur bangunannya. Penelitian ini bertujuan mengidentifikasi bagaimana Budaya Tionghoa dapat bertahan dengan eksistensi nilai arsitektur bangunannya. Pemahaman terhadap karakteristik Arsitektur Tionghoa menjadi sangat penting dalam memahami perkembangan budayanya. Penelitian ini dibatasi pada ruang lingkup arsitektur tradisional. Pemilihan wilayah studi juga berkaitan dengan perbandingan Arsitektur Tionghoa pada budaya barat dan timur. Interpretasi deskriptif berdasarkan persamaan dan perbedaan arsitektur bangunan akan menjelaskan bagaimana Etnis Tionghoa mampu meminimalisir pengaruh budaya lain terhadap karakter arsitekturnya. Hasil penelitian menunjukan identitas arsitektur tradisional Tionghoa terbentuk dengan konsistensi terhadap nilai kepercayaanya. Sementara kepercayaan adalah landasan utama yang membentuk Kebudayaan Tionghoa. Oleh karena itu, refleksi eksistensi Budaya Tionghoa akan berimplikasi terhadap eksistensi identitas arsitekturnya.
\end{abstract}

Kata Kunci : Identitas, arsitektur, Tionghoa

\begin{abstract}
Culture is a process of mindset development that occur gradually over a long time. This process occurs during human life on earth and continue to evolve in accordance with the development of scientific knowledge. The environment setting is one of the factors that play a strong role in shaping the cultural character. Chinese is ethnic which has a lot of migration to other areas such as western and asian regions, either by trading or expedition. Currently, many Chinese settlement areas are found in several places, called Pechinan or China town. The interesting one is the difference of environment where they live does not make the existence of their culture are fade. From several characters of Chinese culture, the most prominent is the architecture. This happens because of cultural forms is most easily seen in form of physical or architecture of the building. This study aims to identify how the Chinese culture can survive with the existence of architectural value. Understanding about Chinese architecture characteristic is very important to understand the development of the culture. This study limited only to the scope of traditional architecture. The selection of study area is also related to the comparation of Chinese architecture in western and eastern culture. Descriptive interpretation based on similarities and differences in the architecture of the building were able to explained how the Chinese ethnic minimize other cultural influences on the character of the architecture. The results showed that the traditional Chinese architectural identity is formed by the consistency of the religious value. While religion is the major base in the Chinese cultural forming. Therefore, the reflection of existence of Chinese culture have implications for the existence of their architectural identity.
\end{abstract}

Keywords: Identity, architecture, Chinese 


\section{Pendahuluan}

Tionghoa merupakan etnis yang mampu mempertahankan eksistensinya di tempat, tanpa menghilangkan karakter budayanya. Fenomena ini menunjukan Etnis Tionghoa mampu mempertahankan identitas budayanya dari pengaruh budaya lain dari lingkungan yang berbeda. Keberlangsungan Budaya Tionghoa juga ditunjukan dengan konsistensi identitas arsitekturnya yang sangat khas sehingga menjadi simbol keberadaan mereka di tiap lingkungan yang mereka tinggali.

Pada perkembangan berikutnya, penyebaran kebudayaan Tionghoa mencapai ke wilayah barat dan asia. Hal itu ditunjukan dengan banyaknya Permukiman Tionghoa "Pechinan" di wilayah asia dan barat. Pechinan adalah istilah yang digunakan sebagai referensi permukiman yang mayoritas dihuni oleh komunitas Tionghoa di luar wilayah China. Karakteristik umum yang menjadikan Pechinan sangat khas adalah bentuk arsitektur tradisional yang mewakili budaya Tionghoa. Hal yang menarik adalah masyarakat Tionghoa mampu mempertahankan eksistensi budaya dengan konsistensi bentuk arsitektur tradisional pada bangunannya di berbagai wilayah.

Penelitian ini bertujuan mengidentifikasi bagaimana Budaya Tionghoa dapat mempengaruhi eksistensi arsitekturnya. Untuk mengkaji hal ini, perlu pemahaman secara menyeluruh berkaitan dengan karakteristik Arsitektur Tionghoa:

- Seperti apa karakteristik arsitektur tradisional asli Tionghoa?,

- Seperti apa karakteristik arsitektur tradisional Tionghoa di luar negaranya, China?

- Bagaimana bentuk perbedaan dan persamaan karakter arsitektur Tionghoa di China dan di luar China?

Objek penelitian adalah arsitektur bangunan tradisional Tionghoa, sedangkan wilayah studi dibatasi pada wilayah Indonesia, wilayah Kanada dan Amerika. Pemilihan wilayah ini didasarkan pada beberapa fakta yang menunjukan di wilayah tersebut berkembang kebudayaan Tionghoa yang berasal dari migrasi masa lalu yang ditunjukan dengan arsitektur bangunannya.

Wilayah Indonesia akan mempresentasikan afiliasi budaya timur terhadap Budaya Tionghoa dan wilayah Kanada dan Amerika akan mempresentasikan afiliasi budaya barat terhadap Budaya Tionghoa. Pemahaman karakteristik arsitektur di wilayah tersebut menjadi penting berkaitan dengan bagaimana Budaya Tionghoa dapat bertahan dengan arsitekturnya yang khas di tempat lain dengan lingkungan yang berbeda.

Pembahasan terhadap identitas arsitektur tradisional Tionghoa akan ditinjau dari aspek Budaya Tionghoa. Oleh sebab itu diperlukan juga pemahaman terhadap Budaya Tionghoa berdasarkan:

- Konsep dasar Budaya Tionghoa.

- Hubungan Budaya Tionghoa dengan arsitekturnya.
Penelitian ini merupakan penelitian kualitatif-deskriptif dengan analisis perbandingan. Analisis perbandingan akan digunakan untuk membandingkan karakteristik Arsitektur Tionghoa di wilayah studi. Perbedaan dan persamaan akan mendefinisikan tingkat eksistensi identitas Arsitektur Tionghoa.

\section{Kajian Literatur}

Identitas didefinisikan sebagai karakter yang dimiliki oleh suatu individu yang dibagi ke seluruh anggota komunitas tertentu atau kelompok. Identitas menjadi dasar ciri komunitas tertentu yang membedakan dengan komunitas lainnya. Rapoport (dalam Catanese \& Snyder, 1991) mengungkapkan bahwa arsitektur bermula sebagai tempat bernaung

Sedangkan menurut 'O'Gorman (1997), arsitektur lebih dari sekedar suatu pelindung. Arsitektur bisa jadi merupakan suatu wujud seni, namun memiliki perbedaan, yaitu arsitektur menggunakan seni sebagai sesuatu yang penting untuk digunakan sebagai interior.

Dua pengertian diatas memaparkan pengertian arsitektur berkaitan dengan lingkungan fisik. Namun menurut Catanese \& Snyder (1991), makna arsitektur jauh lebih luas dari sekedar lingkungan fisik, pengertian arsitektur merupakan bagian dari makna sosial budaya. Lebih lanjut menurut Wigglesworth dan Till (1998), arsitektur memiliki makna yang sangat sulit di jelaskan, terkesan kabur. Sehingga mereka menyimpulkan bahwa kehidupan sehari hari merupakan kritik terhadap arsitektur.

Menurut Banks (1989), budaya dapat digambarkan sebagai keseluruhan pola pikir yang mempengaruhi perilaku setiap individu. Budaya merupakan pengetahuan tentang simbol-simbol, ide-ide, aspek-aspek intangible dari suatu komunitas. Sedangkan menurut Damen (1987), Budaya merupakan pola-pola pengetahuan kehidupan seharihari manusia yang menggambarkan bagaimana mereka berintaraksi.

Beberapa teori budaya juga mendefinisikan pemaknaan yang sama, yaitu berkaitan dengan

- Perkembangan dari satu generasi ke genarasi lain.

- Pola, simbol, dan kategori dari suatu komunitas.

- pemikiran secara eksplisit dan implisit, rasional dan irasional.

- Perilaku; menerima, menginterpretasi, berekspresi maupun merespon.

Menurut Dr. J. F. García, seorang pengajar di Universitas Ashland, Ohio pada website-nya memaparkan ada 5 elemen budaya yaitu:

- Material Culture Meliputi komponen produk yang berkaitan dengan bentuk, infrastruktur,dan teknologi.

- Social Institution

Meliputi pemerintahan, rumah tangga dan organisasi non pemerintah.

- Man and universe

Meliputi kepercayaan, agama, keimanan, 
dan mistik.

- Aesthetic

Meliputi segala bentuk karya senidiantaranya seni musik, seni lukis ataupun seni teater.

- Language (Verbal and Non Verbal, Body) Berkaitan erat dengan bahasa baik bahasa verbal maupun non verbal.

Arsitektur merupakan sebuah produk budaya yang diciptakan dengan teknologi pada masanya. Oleh sebab itu berdasarkan elemen budaya diatas, arsitektur merupakan bagian dari elemen Material Culture. Pembahasan berikutnya akan lebih fokus terhadap arsitektur sebagaai salah satu produk budaya.

\section{Budaya Tionghoa}

Budaya Tionghoa merupakan keseluruhan pola pikir masyarakat Tionghoa yang membentuk satu kesatuan kepentingan sehingga dapat menggambarkan etnis Tionghoa sebagai kelompok yang mewakili budaya Tionghoa.
Menurut Kupier (2011), berdasarkan sejarahnya Dinasti Han merupakan dinasti yang paling berperan dalam membentuk kebudayaan Tionghoa. "Han" merupakan etnis terbesar yang tersebar di seluruh provinsi di Tionghoa kecuali provinsi Tibet dan Xinjiang. Hal yang paling mendasar dari gaya hidup etnis Tionghoa adalah mereka sangat memaknai ajaran para leluhurnya. Konsep ajaran Yin dan Yang yang muncul pada masa ajaran Doism diterapkan pada hampir semua aspek kehidupan bahkan yang paling sederhana sekalipun.

\section{Penyebaran Etnis Tionghoa}

Tionghoa sudah mengenal berbagai negara didunia sudah sejak lama, baik dengan hubungan perdagangan maupun ekspedisi (Wade, 2007). Gambar 1 merupakan peta lama yang menjelaskan bahwa bangsa Tionghoa sudah mengenal negara-negara didunia pada tahun 1418 dengan ekspedisi dibawah kepemimpinan Admiral Zheng He.

\section{Masyarakat Tionghoa di China}

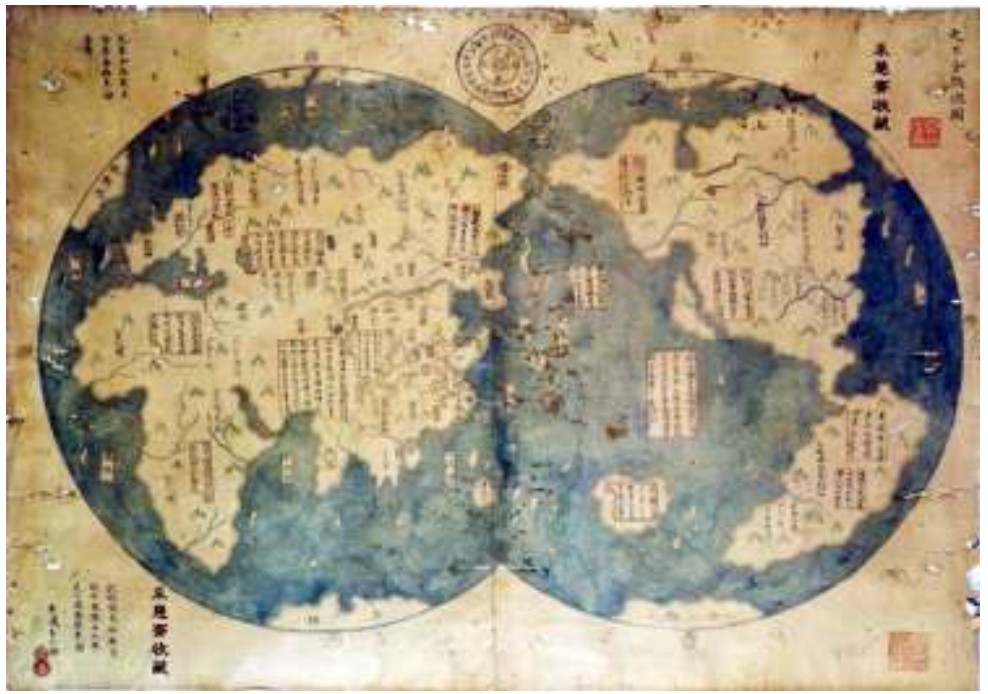

Gambar 1. Peta dunia china pada tahun 1418 Sumber: Wade, 2007

Fakta memperlihatkan etnis Tionghoa mampu berkembang secara bergenerasi di wilayah yang domainnya bukan di negara asalnya. Namun yang menjadi keistimewaan bangsa tionghoa adalah dimana pun mereka berada tetap membawa budaya asli mereka.

\section{Kepercayaan}

Agama pertama di Tionghoa masih dalam perdebatan para ahli. Berdasarkan sejarah, masyarakat Tionghoa lebih dulu mengenal ajaran-ajaran kebijakan oleh leluhurnya. Dalam kebudayaan Tionghoa awal, yang membentuk falsafah hidup masyarakat Tionghoa adalah ajaran-ajaran yang diperkenalkan oleh Confucius, Laozi dan buddha (Kupier, 2011).

Menurut Taylor (1982) dalam bukunya yang berjudul "Proposition and Praxis: The Dilemma of Neo-Confucian Syncretism", agama-agama di Tionghoa lebih beorientasi pada sistem kekeluargaan tanpa menuntut kepatuhan anggotanya secara eksklusif. Bahkan banyak peneliti yang meragukan istilah "agama" dalam referensi buddhisme atau Toisme, mereka lebih memilih istilah "cara berfikir".

Lebih lanjut Kupier (2011) menuliskan ajaran filosof Tionghoa yang cukup terkenal adalah Daoism atau lebih dikenal dengan Taoism yang sudah berkembang hampir lebih dari 2000 tahun yang lalu. Tao bermakna "cara" atau "jalan" untuk mencapai keharmonian dengan alam semesta.. Ajaran-ajaran Taoisme adalah gabungan anarkisme dan kepercayaan bahwa kebenaran di luar pemahaman manusia dapat diperoleh dengan cara bersemadi atau tasawuf. Ada 3 konsep dasar ajaran Taoism yaitu; 1) hubungan antara alam dan manusia, interaksi antara lingkungan dan masyarakat, 2) siklus transformasi kehidupan di alam semesta dan 3) penyembahan terhadap nenek moyang. 
Ajaran filosof masyarakat Tionghoa lainnya yang cukup terkenal adalah Confucianisme yang dibawa oleh pemikir Confucius. Ajaran tersebut mengajarkan tentang tata cara menjalani kehidupan dan bagaimana berfikir bijak. Confucianisme tidak dianggap sebagai satu agama yang berunsurkan ketuhanan tetapi merupakan ajaran yang mengajarkan tentang prinsipprinsip hidup yang lebih baik. Confucianisme berasaskan ajaran Confucius dapat dirumuskan dalam konsep Jen yang menekankan perasaan perikemanusiaan terhadap masyarakat lain dan harga diri.

Ajaran Confucius lebih melihat ke masa lalu, bagaimana memahami kehidupan, mempelajari cara-cara hidup tradisional yang menurutnya akan mengurangi potensi regenerasi ke masa depan, berkenaan dengan $L i$ atau rukun bangsa serta berkaitan dengan bagaimana keamanan dan kepatuhan menjadi bagian dari negaranya.

Taoisme dan Confucianisme bukan merupakan agama yang berunsurkan kepercayaan ketuhanan melainkan adalah agama yang berkembang dari falsafah masyarakat yang menganutinya.

Kepercayaan lainnya pada kebudayaan Tionghoa adalah ajaran Buddhism atau dikenal dengan sebutan ajaran Buddha yang diperkenalkan India dimasa Dinasti Han. Berbeda dengan ajaran Confucianisme dan Taoisme, ajaran buddha menganut prinsip ketuhanan dengan Buddha sebagai Kekuasaan tuhan tertinggi. Ajaran tersebut merupakan ajaran yang berasal dari luar Tionghoa (india) namun karena cara berfikirnya sejalan dengan ajaran daoism, ajaran ini dapat diterima oleh masyarakat Tionghoa (Maspero, 1981).

Kepercayaan-kepercayaan yang berkembang pada masyarakat Tionghoa membentuk identitas dan menjadi bagian dari budaya hidup mereka. Bahkan Agama Buddha dapat berkembang pesat karena memang ajarannya sejalan dengan ajaran daoism.

\section{Arsitektur Tradisional Tionghoa}

Keunikan arsitektur tradisional Tionghoa adalah penggunaan kayu sebagai material konstruksi utama (Kupier, 2011). Bangunan arsitektur di Tionghoa umumnya memiliki karakteritik utama sebagai berikut: 1) prestasi terbesarnya yaitu maha karya istana kerajaan dan penataan kota, yang mencerminkan sistem pemerintahan kekaisaran dan struktur sistem sosial, 2) Court yard didepan bangunan, secara simetris menjadi umbu bangunan utama, 3) Menyesuaikan dengan alam.

Menurut David G. Khol (1984:22) dalam bukunya menuliskan ciri khas arsitektur Tionghoa di Asia Tenggara adalah sebagai berikut:

\section{- "courtyard"}

- Elemen-elemen struktural yang terbuka (yang kadang-kadang disertai dengan ornamen ragam hias)

- Penekanan pada bentuk atap yang khas.

- Penggunaan warna yang khas.

Sedangkan menurut $G$. Lin dalam Widayati (2004), karakteristik Arsitektur Tionghoa yang perlu dibahas dan dikenali adalah ;

- Organisasi ruang

- The Jian

- Axial Planning

\section{Courtyard \& Elemen-elemen struktural yang terbuka}

Courtyard (gambar 2) merupakan ruang terbuka pada hunian tradisional Tionghoa. Ruang terbuka ini sifatnya lebih privat. Biasanya digabung dengan kebun/taman (Khol, 1984).
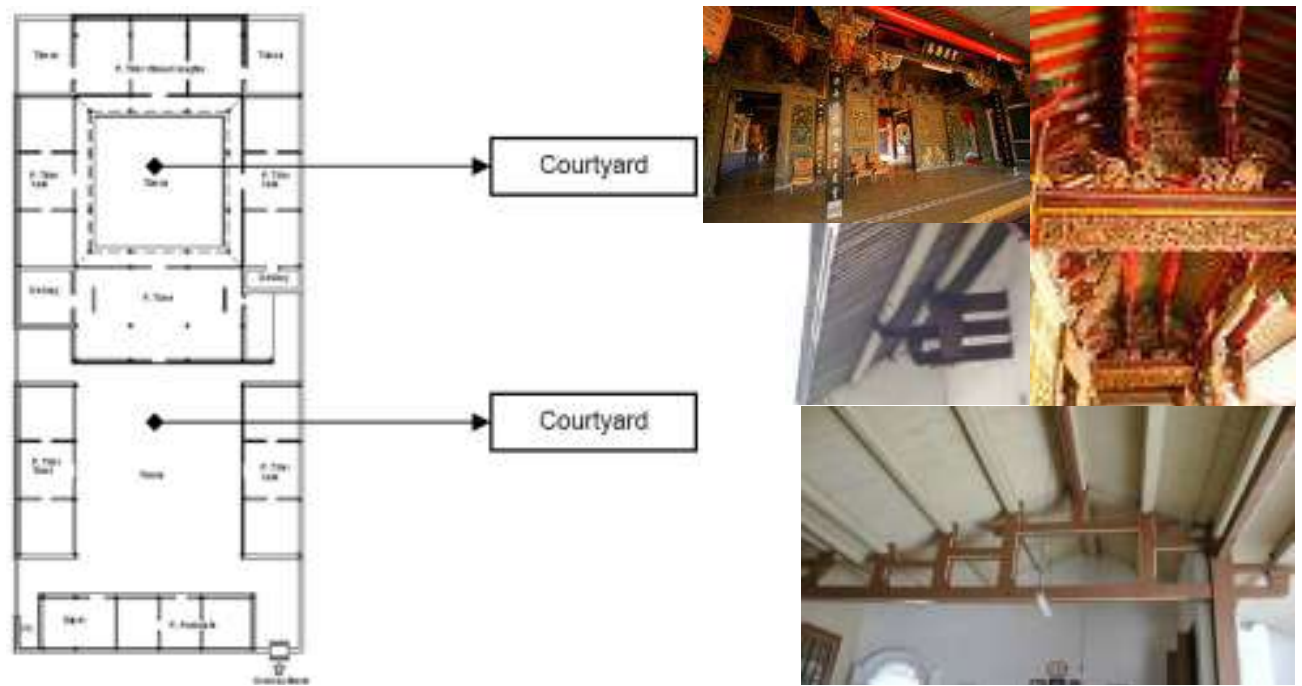

Gambar 2. Tipe Hunian Tradisional Tionghoa dengan Courtyard

Sumber: Handinoto, 2008

\section{Penggunaan warna dan bentuk Atap yang Khas}

Penggunaan warna yang khas juga melambangkan simbol-simbol tertentu dan menunjukan makna "keyakinan" (gambar 3). Bentuk atap yang khas pada hunian tradisional Tionghoa dapat dilihat pada ujung perubung atapnya yang berbentuk melengkung (gambar 4). 

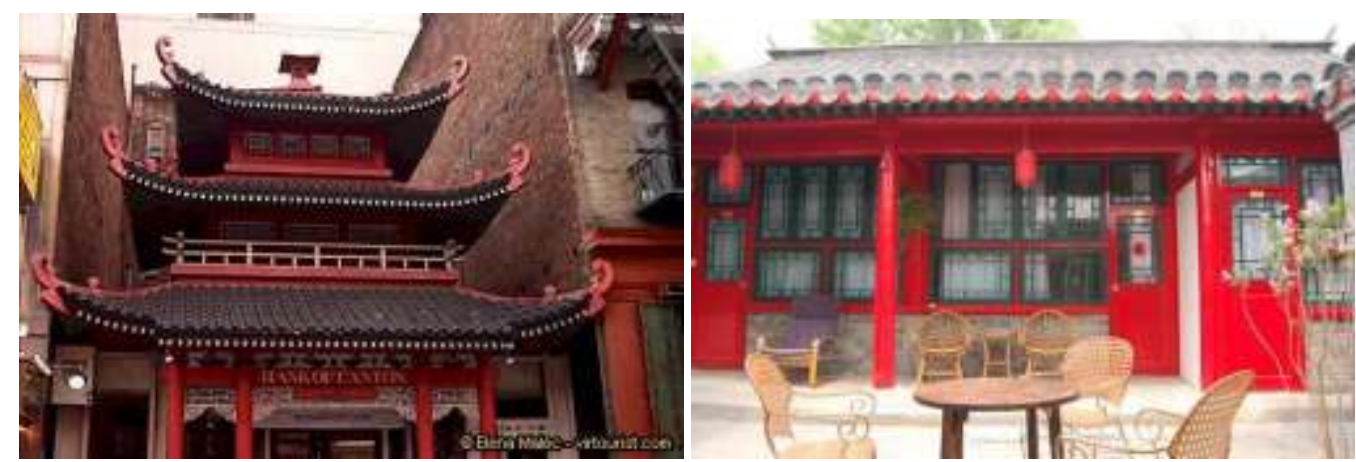

Gambar 3. Elemen warna pada bangunan Tionghoa

Sumber: Handinoto, 2008

a

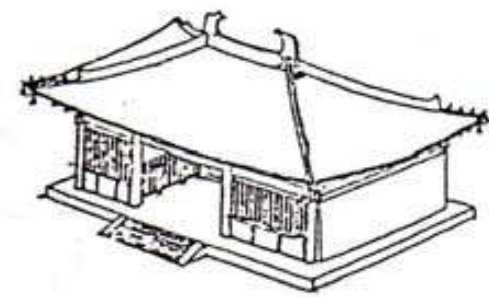

b

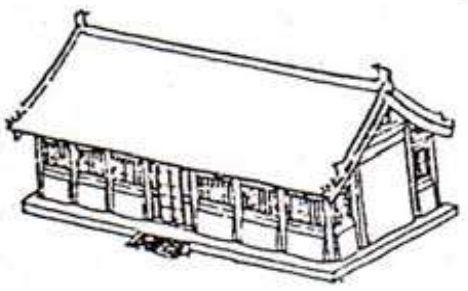

d

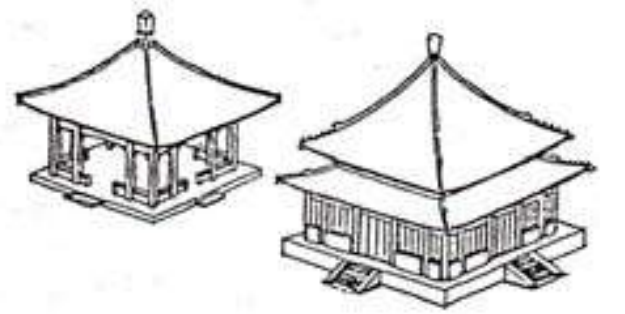

e

Gambar 4. a) atap model Wu Tien, b) atap model Hsun Shan, c) atap model Hsun Shan, d) atap model Ngang Shan, e) atap model Tsuan Tsien

Sumber: Handinoto, 2008

\section{Organisasi Ruang}

Seperti yang diuraikan oleh G. Lin (1989) dalam Widayati (2004), Organisasi ruang pada Arsitektur China didasarkan pada kebutuhan hidup sehari-hari yang dipadukan dengan persyaratan-persyaratan estetika yang dianut masyarakat Tionghoa: Ada dua karakteristik yang cukup dominan dalam konsep penataan ruang Bangunan tradisional Tionghoa yaitu Jian dan Axial Planing

\section{Jian}

Jian merupakan unit dari organisasi ruang. Konsep dasarnya meliputi penggunaan Jian, atau bay room, sebagai standar unit atau modulasi dan dapat dikembangkan atau dibuat secara berulang menjadi suatu massa bangunan atau beberapa kelompok bangunan.

Jian adalah sebuah ruang persegi empat atau suatu ruang yang diberi pembatas dinding atau hanya dibatasi oleh kolom sehingga secara psikologis juga membentuk sebuah ruang. Jian juga dapat ditambahkan untuk membentuk suatu ruang (hall) atau ting dengan menggunakan unit standar sepanjang sumbu longitudinal (berulang memanjang secara menerus) 
dan sumbu horizontal.

\section{Axial Planning}

Karakteristik berikutnya dari arsitektur Tionghoa klasik adalah bentuk struktur yang simetri dan orthogonal pada denah dan potongan. Hal ini merupakan sumber dari kosmologi Tionghoa. Pada Arsitektur Tionghoa hall dan courtyard ditempatkan sepanjang suatu axis longitudinal atau suatu jalan setapak (path) pada susunan orthogonal.

Ruang-ruang tersebut terpisah satu dengan lainnya dengan adanya courtyard yang pada akhirnya dianggap sebagai ruang utama pada komposisi secara keseluruhan (gambar 5):

- Sumbu longitudinal adalah sumbu utama sedangkan sumbu horizontal adalah sumbu sekunder.

- Namun ada kalanya dalam suatu komposisi hanya ada satu sumbu atau tidak ada sumbu sama sekali.

Bentuk dasar organisasi ruang bangunan tradisional Tionghoa adalah berbentuk persegi panjang, dengan unit ruang yang menyatu dalam keseluruhannya. Arsitektur Tionghoa mengkombinasikan bentuk persegi panjang bervariasi dalam ukuran dan posisi sesuai dengan kebutuhannya. Kombinasi dari unit ruang dalam arsitektur tradisional Tionghoa mematuhi prinsip-prinsip keseimbangan dan simetri. Struktur utama adalah sumbu, dan struktur sekunder diposisikan sebagai dua sayap di kedua sisi untuk membentuk ruang-ruang utama dan halaman.

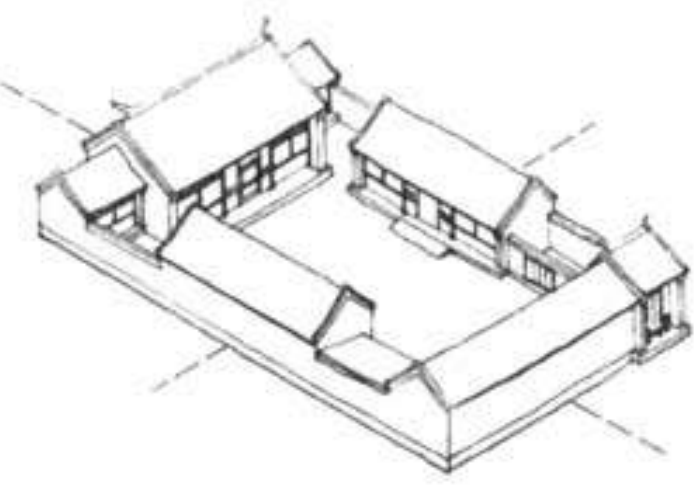

Gambar 5. Simetri pada Arsitektur China Sumber: Handinoto, 2008

\section{Pengaruh Kepercayaan Terhadap Arsitektur Tradisional Tionghoa}

Pengaruh budaya pada Arsitektur Tionghoa dapat diidentifikasi dari konsepkonsep perencanaan yang keseluruhannya menerapkan konsistensi ajarannya. Sama halnya dengan aktivitas keseharian mereka, arsitektur juga menjadi bagian dari pengamalan ajaran dan kepercayaan mereka. Berikut beberapa hal mengenai arsitektur dan bangunan yang secara langsung terkait dengan kepercayaan mereka.

\section{Feng Shui}

Menurut Salem dalam bukunya yang berjudul "A Teacher's Sourcebook for Chinese Art \& Culture" , Feng Shui merupakan suatu metode yang digunakan masyarakat Tionghoa dalam menentukan arah orientasi kota, rumah, atau gua untuk memperoleh energi dari elemen georafis dan lansekap seperti air, gunung dan celestial bodies.

Praktek Feng Shui sudah ada sebelum ajaran Taoisme, namun sampai sekarang sudah dianggap sebagai manifestaasi dari hidup harmoni dengan kekuatan alam. Filosofi Feng Shui adalah keseimbangan dengan alam sama halnya dengan Yin dan Yang. Jika yin dan yang adalah prinsip keseimbangan yang diterapkan dalam seni bela diri, maka feng shui merupakan prinsip keseimbangan alam yang diterapkan pada arsitektur.

\section{Pola Penataan Ruang}

Pola penataan ruang masyarakat Tionghoa yang menerapkan tata ruang dalam yang dikenal dengan istilah "inner court" atau "courtyard" merupakan penjabaran dari pemikiran Confusius. Penataan courtyard bagi penghuninya dapat membentuk suatu dunia kecil (sebagai ruang pribadi). Hal ini sesuai dengan kepercayaan masyarakat Tionghoa terhadap Feng Shui (Widayati, 2004).

Untuk Qi (breath) dalam kelompok bangunan, maka kelompok bangunan tersebut diarahkan ke void (lubang). Bentuk geometris berperan dalam organisasi ruang, dengan bentuk sederhana dapat menghadirkan courtyard segi empat.

Seluruh bangunan yang berlantai satu besar atau kecil akan direncanakan atau dibangun dengan aturan-aturan tertentu di sekeliling courtyard. Hal ini sesuai dengan pandangan hidup masyarakat Tionghoa "dekat dengan tanah/bumi" (close to the earth) atau apabila manusia dekat dengan tanah atau bumi maka kesehatannya terjamin.

\section{Langgam dan Gaya}

Langgam dan gaya bangunan arsitektur Tionghoa dapat dengan jelas dilihat dari ornamen bagian atas atap atau ornamen pada kolom-kolom bangunan yang seluruhnya menggambarkan lukisan bunga atau binatang. Ukiran dan ornamen 
ini memiliki arti tersendiri terhadap kepercayaan masyarakat Tionghoa.

\section{Arsitektur Tradisional Tionghoa Di Indonesia}

Penyebaran masyrakat Etnis Tiongkok di tanah jawa terjadi dengan alasan perdagangan dan usaha menyelamatkan diri dari pemerintahan Ching dan akhirnya membentuk koloni permukiman, salah satunya di Pulau Jawa (Carey, 1985:86). Di kawasan pesisir utara pulau Jawa, arsitektur Tionghoa berkembang pada abad ke-14 yang didominasi etnis Tionghoa dari Tiongkok Selatan.

Sebagian besar masyarakat Tiongkok yang terdampar di Pulau Jawa menikah dengan wanita setempat dan mendirikan permukiman dengan izin penguasa pribumi. Penyebarannya meliputi wilayah: Semarang, Beyaran, Demak, Kudus, Pati, Juwana, Rembang, Lasem, Welahan, Jepara dan Tayu.

Budaya Tionghoa mengalami pasang surut, pada masa penjajahan Belanda, pasca era kemerdekaan pada tahun 1965 dan awal-awal lahirnya era reformasi pada tahun 1998. Ditandai dengan terjadi kerusuhan berlandaskan rasis dimana etnis Tionghoa menjadi sasaran dengan motif kecemburuan sosial.

Pernikahan antara Etnis Tionghoa dan masyarakat pribumi melahirkan keturunan yang disebut tionghoa peranakan atau masyarakat Tionghoa yang telah beberapa generasi tinggal menetap di tanah Jawa. Budaya hidup mereka sudah bercampur dengan budaya masyarakat Jawa dan mereka tidak lagi menggunakan bahasa Tionghoa sebagai bahasa sehari-hari mereka, misalnya penanggalan Tionghoa yang diakulturasikan dengan penanggalan Jawa.

\section{Pengaruh kosmologi terhadap rumah ibadah-Kelenteng}

Klenteng Sam Po Kong terletak di kawasan komplek gedung batu di wilayah Simongan, Semarang Barat. Pada awalnya klenteng ini merupakan sebuah masjid yang didirikan oleh keturunan Tionghoa Muslim Semarang. Arsitektur klenteng ini merupakan perpaduan budaya Jawa dan China. Klenteng Sam Po Kong terdiri dari tiga bagian utama, yaitu Kuil Mbah Juru Mudi, Kuil Sam Po Kong dan Kuil Dewa Bumi. Ketiga kuil ini memiliki kemiripan dengan konsep-konsep arsitektur Istana Terlarang di China dengan ciri khas gaya atap dan warna bangunan. Atap yang bertumpuk tiga melambangkan kelopak teratai. Sedangkan warna yang dominan pada setiap bangunan di Klenteng Sam Po Kong adalah merah, kuning, dan hijau. Dalam budaya Cina, warna merah melambangkan kebahagiaan dan menolak pengaruh jahat, warna hijau merepresentasikan warna alam ${ }^{1}$.

${ }^{1}$ Dian Maya Safitri, "Belajar Tentang Nilai-Nilai Pluralisme Islam Jenderal Cheng Ho Melalui Sinkretismed Abangan, Islam,
Keseluruhan prinsip-prinsip arsitektur Klenteng Sam Po Kong menunjukan budaya China masih sangat melekat dan mendominasi walaupun berada jauh dari tanah kelahirannya (lihat gamba 7).

\section{Pengaruh Kosmologi Terhadap Arsitektur Rumah Toko di Semarang}

Ruko (rumah-toko) secara harafiah dapat diartikan dan dipahami sebuah bangunan yang berfungsi ganda, yaitu sebagai rumah dan toko (aktifitas komersial) dimana aktivitas komersial dibagian depan lantai dasar dari bangunan dua lantai sedangkan aktivitas berumah tinggal di bagian belakang lantai dasar dan lantai atasnya. Pratiwo (2010) dalam bukunya yang berjudul "Arsitektur Tradisional Tionghoa dan Perkembangan Kota", mengatakan bahwa denah ruko dikawasan pechinan Semarang sangat panjang dengan tampak depan yang sempit. Ruko dibangun bersebelahan dengan tembok bersama antara rumah yang satu dengan rumah yang lainya. Tatanan ruangnya berdasarkan pada kepercayaan fengshui agar penghuninya selalu beruntung. Tipe bangunan seperti ini telah digunakan orang Tionghoa sejak lama dan bentuk-bentuk dasarnya ditemukan di kota-kota perairan Tiongkok Selatan. Tipe rumah ini dapat diklasifikasi lagi kedalam tiga subtype. Rumah deret satu lantai, rumah dua lantai dengan teras, dan dua lantai tanpa teras.

\section{Arsitektur Tradisional Tionghoa Di Amerika Serikat}

Imigran asal Tionghoa mulai berlayar ke Amerika Serikat pada akhir abad 17. Kedatangan masyarakat Tionghoa pertama tercatat pada tanggal 9 agustus tahun 1785 di Baltimore dengan motivasi perdagangan. Namun alasan kedatangan masyarakat Tionghoa paling utama adalah pada pertengahan abad 18 yaitu pertambangan emas $^{2}$. Wong (1998) dalam bukunya yang berjudul "Ethnicity and Entrepreneurship:The New Chinese Immigrants in the San Francisco Bay Area", menuliskan kedatangan imigran terbanyak pertama berlangsung mulai tahun 1850 . Gelombang imigran terus berdatangan hingga tahun 1890 dengan jumlah populasi mencapai 107.488 jiwa.

Sedangkan menurut Chen (2011), gelombang kedatangan masyarakat Tionghoa di Amerika di bagi menjadi 4 tahap. Tahap pertama pada periode tahun 1948 hingga 1882, sebagian besar bertempat tinggal di California dengan motivasi pertambangan emas. Tahap kedua pada tahun 1882-1943 dengan motifasi pekerjaan. Tahap ke tiga pada

\footnotetext{
Taoisme, Dan Budha Di Klenteng San Po Kong"., artikel mahasiswa Pasca Sarjana UGM (h 30-32).

Berdasarkan artikel "Chinese American Heroes", chineseamericanheroes.org, diakses 7 Maret 2014
} 
tahun 1943-1924 dengan motivasi aliansi antara negara China dan Amerika dalam melawan Jepang di Perang dunia ke-2. Terakhir tahap ke empat diatas tahun 1965 dengan motivasi adanya pengakuan hukum amerika terhadap imigran asal China sebagai warga negara. Kedatangan masyarakat Tionghoa di Amerika sudah berlangsung sangat lama dan bergenerasi sehingga komunitasnnyapun semakin bertambah. Masing-masing komunitas membentuk perkumpulan dan permukiman agar dapat saling membantu dalam hidup diperantauan. Permukiman-permukiman ini dikenal dengan istilah-istilah Chinatown atau Pechinan.

Di Amerika terdapat beberapa Chinatwon atau Pechinan, antara lain terletak di kota San Fransisco, New York dan Seattle. Chinatown atau Pechinan merupakan sebuah wilayah kota yang mayoritas penghuninya adalah masyarakat Tionghoa.

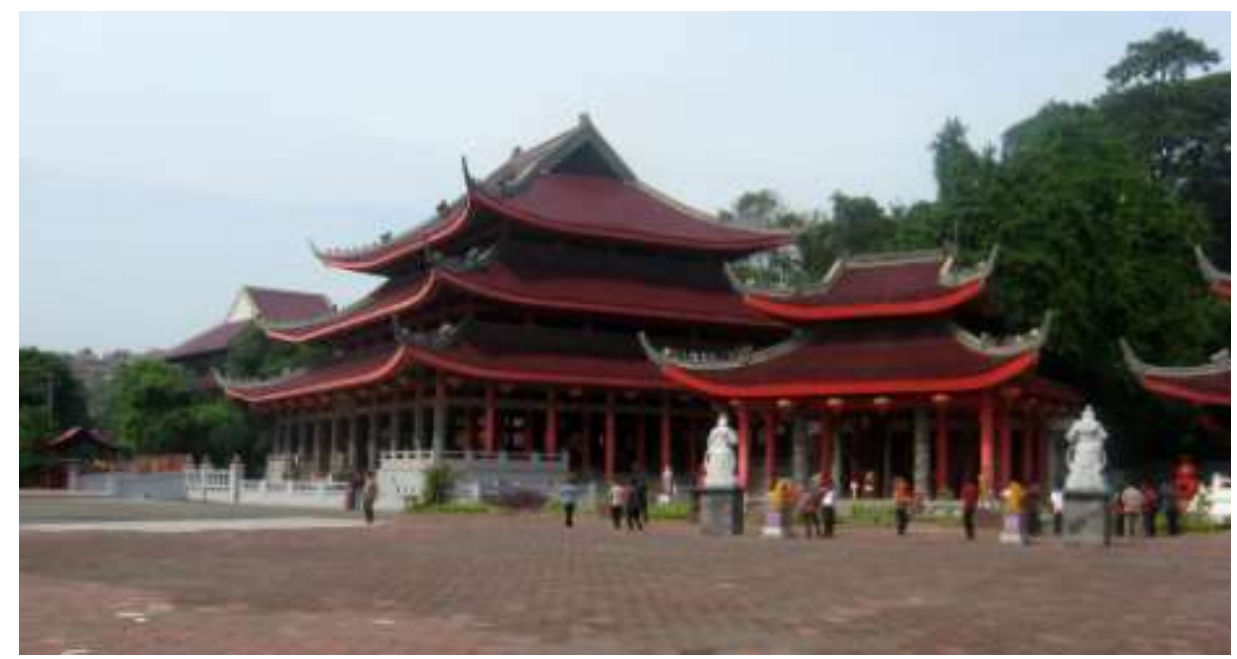

Gambar 7. Klenteng Sam Pho Kong

Sumber: http://en.wikipedia.org/wiki/Sam_Poo_Kong, diakses 5 Maret 2014

\section{Bangunan ibadah (Kelenteng) di Amerika Serikat}

Kelenteng pada masa awal kedatangan masyarakat Tionghoa ke Amerika hanya berjumlah 8 buah. Namun dalam perkembangannya hingga sekarang kelenteng di Amerika sudah berjumlah berjumlah ratusan. Salah satu contoh kuil yang ada di Amerika adalah kuil Hsi Lai. Kuil Hsi Lai adalah kuil terbesar yang ada di Amerika, Hemisphere ${ }^{3}$.

Kuil Hsi Lai dibangun pada tahun 1978 dan dibuka untuk publik pada tahun 1988. Kuil ini didesain dengan prinsip arsitektur China dengan fungsi utama sebagai tempat ibadah. Prinsip-prinsip struktural arsitektur China sebagian besar tetap tidak berubah, perubahan utama hanya pada penyesuaian lingkungan tapak.

Dari segi arsitektur, tidak ada perubahan mendasar yang ada pada kuil di Amerika dengan kuil di China. Warnawarna cerah mendominasi warna pada kuil ini. Kolom-kolom dibangun dengan bentuk bulat dengan proporsi yang seimbang dengan atapnya.

Karakteristik yang paling dominan adalah penekanan pada artikulasi dan simetri bilateral, yang berarti keseimbangan. Simetri bilateral dan artikulasi bangunan ditemukan di mana-

\footnotetext{
${ }^{3}$ Donald E. Miller, Jon Miller, Grace R. Dyrness , dkk,. 2011. "Immigrant Religion in the City of Angels". Center for Religion and Civic Culture. University of Southern California (h 27)
}

mana dalam arsitektur Tionghoa, dari kompleks istana hingga rumah-rumah pertanian yang sederhana. Hal ini terlihat jelas dari arsitektur kuil Hsi Lai. Kuil ini menerapkan pada simetri bilateral yang melambangkan keseimbangan (gambar 8).

\section{Chinatown di seattle}

Chinatown di Seattle banyak memiliki bangunan bersejarah yang dibangun antara 1909 dan 1929. Sebagian besar Chinatown di Seattle terdiri dari restoran, galeri, tokotoko souvenir dan rumah tinggal. Pada Chinatown di Seattle ornamen naga dipercayai masyarakat tionghoa disana sebagal simbol keberuntungan. Mereka berjuang untuk mempertahankan simbosimbol yang ada pada arsitektur mereka sebagai warisan budaya dan arsitektur mereka 4 .

Material bangunan yang digunakan untuk membangun rumah biasanya adalah batu bata yang dicat berwarna merah dengan hiasan-hiasan ornamen khas Tionghoa dan tulisan-tulisan mandarin. Biasanya tulisan-tulisan mandarin menunjukkan identitas dari ruko tersebut (gambar 9).

\footnotetext{
${ }^{4}$ Deskripsi berdasarkan poster Asian American Heritage in Seattle yang ditulis oleh the Cultural Tourism Program of Seattle's Convention and Visitors Bureau (Asian American Cultural Guide, Second Edition, 2010)
} 


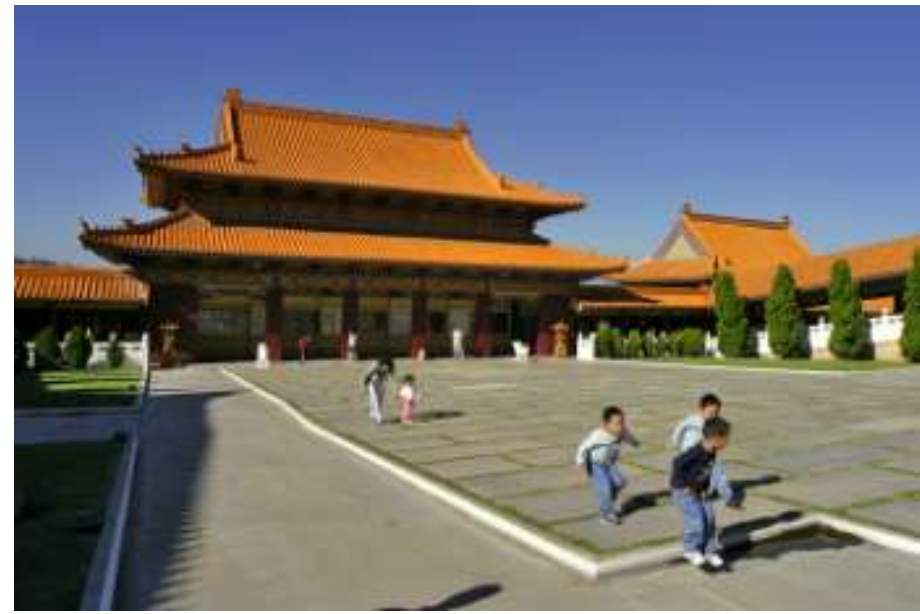

Gambar 8. Kuil Hsi Lai di Amerika Serikat

Sumber: http://en.wikipedia.org/wiki/Chinese_enclaves_in_the_San_Gabriel_Valley diakses 7 maret 2014

\section{Bentuk Atap Arsitektur Tionghoa di Vancouver, Kanada}

Menurut Wong (1992) dalam Guo (2006) ada tiga gelombang besar kedatangan masyarakat Tionghoa ke Kanada sejak perang dunia ke-2. Gelombang pertama pada tahun 1958 hingga 1961 dengan motivasi perubaahan politik agrikultur Hong Kong. Gelombang kedua terjadi pada tahun 1967 yang diduga akibat efek domino pasca perang dunia ke-2. Gelombang ketiga terjadi pada mulai tahun 1980 akibat ketidak percayaan warga Tionghoa Hong Kong dengan perjanjian kerjasama antara inggris dan Hongkong. Mereka meninggalkan Hong Kong dan pindah ke Kanada. Sedangkan menurut Li (1998) dalam Guo (2006) mayoritas imigran masyarakat Tionghoa di Kanada berasal dari tiga Hongkong, Taiwan dan China.

\section{Transformasi Bentuk Arsitektur}

Chinatown di Vancouver didefinisikan dengan arsitektur khas 'balcony-style', dengan arsitektur yang memadukan timur dan barat dalam elemen desainnya. Balcony-style adalah sebuah gaya arsitektur hibrida yang memadukan aspek arsitektur Tionghoa dengan gaya barat. Bangunan-bangunan ini semua dibangun untuk bangunan komersial (gambar 10).

Di Chinatown Vancouver juga terdapat gerbang dengan bentuk atap khas dari etnis Tionghoa. Chinatown Vancouver memiliki pintu masuk berupa dua gerbang khas Arsitektur China. Gerbang pertama adalah menuju ke Pusat Kebudayaan China dan Gerbang Milenium, yang melintasi Jalan Pender di bagian barat kota. Bangunan-bangunan di koridor jalan tersebut merupakan kombinasi antara arsitektur setempat dengan Arsitektur China. Dapat dilihat pada foto (gambar 1112), penggabungan tersebut tidak menciptakan difusi yang erat, namun pemisahan karakter bangunan dalam wadah yang sama. Hal ini memperlihatkan kedua karakter arsitektur tetap muncul dalam bentuk bangunan atau massa yang berbeda.

\section{Ornamen dan simbol}

Bangunan-bangunan komersial seperti rumah toko (ruko) mengalami alkulturasi dengan arsitektur setempat (Kanada). Misalnya ada bangunan yang mengkombinasikan ornamen China dan Barat, atau ada yang mengkombinasikan atap Kelenteng China Selatan dengan fanlights Palladian serta Fujian mural di dinding. Ada pula yang menggabungkan antara kolom Yunani dan Romawi, serta menambahkan motif China lainnya.

Menurut Mckinnon ${ }^{5}$, simbolisme yang digunakan etnis Tionghoa di kota tersebut merupakan kepercayaan mereka terhadap peruntungan nasib serta untuk melindungi mereka dari kekuatan jahat. Umumnya tulisan-tulisan kanji, gambar dan warna yang terkandung merupakan simbol-simbol keberuntungan, umur panjang dan kedamaian. 


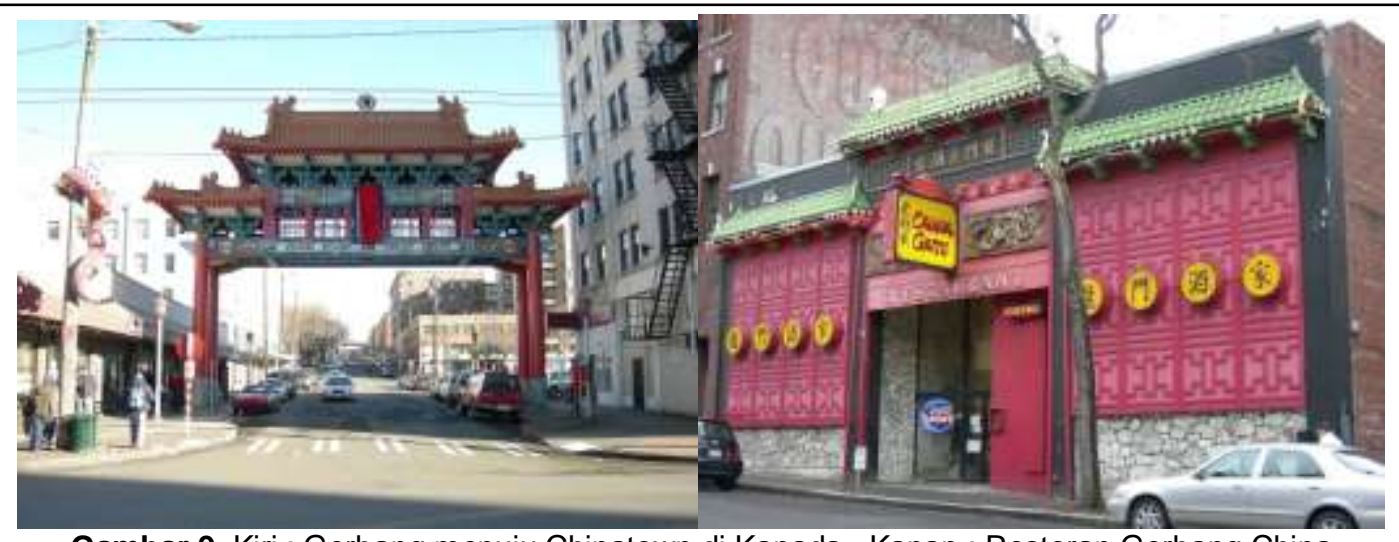

Gambar 9. Kiri : Gerbang menuju Chinatown di Kanada , Kanan : Restoran Gerbang China Sumber: http://en.wikipedia.org/wiki/Seattle_Chinatown-International_District diakses 7 Maret 2014

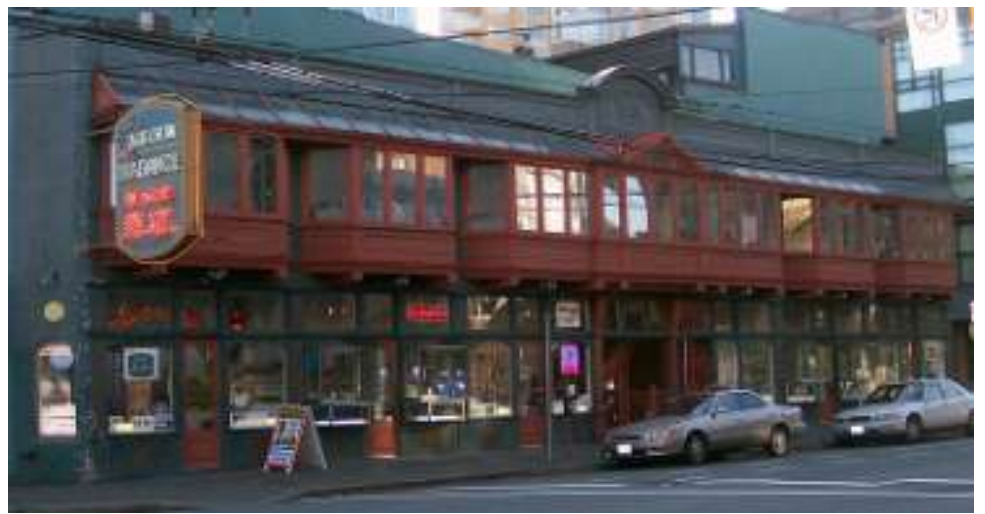

Gambar 10. Rumah Toko Sam Kee di Vancouver Chinatown, Kanada Sumber: http://en.wikipedia.org/wiki/Sam_Kee_Building diakses 11 Maret 2014

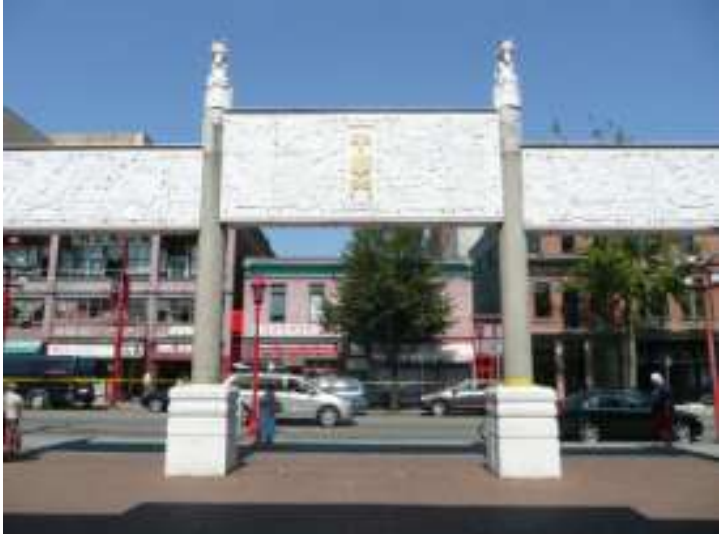

Gambar 11. Gerbang Masyarakat Tionghoa di Pusat Kebudayaan China di Vancouver's Chinatown Sumber: http://commons.wikimedia.org/wiki/File:2010-08_Vancouver_China_Gate.jpg diakses 11 Maret 2014

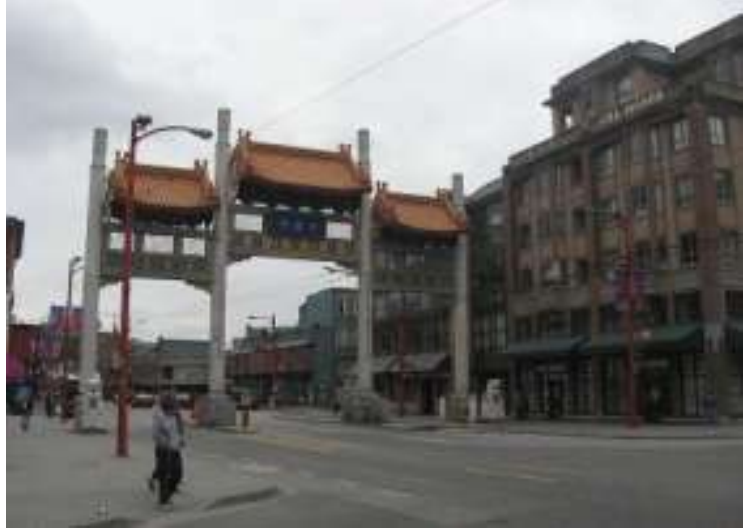

Gambar 12. Gerbang Milenium menuju Jalan Pender di Vancouver's Chinatown Sumber: http://en.wikipedia.org/wiki/Chinatown, Vancouver diakses 11 Maret 2014 


\section{Hasil dan Pembahasan}

Identitas Arsitektur

Tionghoa merupakan karakteristik arsitektur yang dapat mewakili budaya Etnis Tionghoa. Suatu karakter akan menjadi sebuah identitas ketika karakter tersebut memiliki konsistensi terhadap prinsip yang telah disepakati bersama sebagai suatu aturan. Identitas Arsitektur Tionghoa manjadi penting untuk dibahas berkaitan dengan kemampuannya bertahan di berbagai tempat di seluruh dunia.

Seperti yang kita ketahui Etnis Tionghoa sudah berkelana ke berbagai tempat di dunia sejak masa dahulu kala. Dari perjalanan mereka ada yang menetap dan ada yang kembali ke negara asalnya, China. Masyarakat Tionghoa yang menetap akhirnya membentuk komunitas dan menetap secara bergenerasi dan melahirkan permukiman-permukiman bergaya Tionghoa, seperti yang kita kenal dengan istilah Little China, Chinatown atau Pechinan. Hal yang menarik adalah walaupun mereka hidup di luar negaranya dalam jangka waktu yang lama secara bergenerasi, namun budaya mereka masih tetap bertahan sehingga munculah istilahistilah seperti disebutkan sebelumnya.

Salah satu elemen budaya adalah material budaya, yang secara khusus berkaitan dengan produk budaya secara fisik. Arsitektur menjadi bagian yang tidak terpisahkan dari produk fisik budaya, dikarenakan setiap perubahan budaya dapat diidentifikasi dari perkembangan arsitekturnya.

Analisis penelitian ini membahas identitas arsitektural pada bangunan Tionghoa dengan mengkaji tata layout, bentuk, warna dan ornamen. Bangunan yang dianalisis mewakili fungsi hunian dan religius. Analisis dibuat berdasarkan data gambar dari tiga lokasi bangunan berasal (China, Amerika dan Indonesia). Analisis Persamaan dan Perbedaan Karakteristik Arsitektur Tionghoa Di Negara China, Amerika dan Indonesia Dapat dilihat pada tabel 1.

Dari hasil pembahasan perbandingan diperoleh temuan bahwa:

a) Pada pengaturan tata layout bangunan religius di China, prinsip yang digunakan adalah axial planning dan simetris. Hal ini juga diterapkan pada bangunan religius di Amerika dan Indonesia. Sedangkan pada bangunan hunian, prinsip tata layout berupa axial planning dan simetris tetap diterapkan tetapi disesuaikan dengan fungsi dari ruangruang bangunannya. Penggunaan prinsip axial planing dan simetris berkaitan dengan kepercayaan mereka terhadap keseimbangan alam. Keseimbangan alam juga ditunjukan dengan penerapan konsep courtyard pada pengaturan layout bangunan. Ruang courtyard menjadi semacam ruang netral yang membagi ke arah sisisisi courtyard. Hal ini juga yang menyebabkan pengaturan tata layout bangunan masyarakat Tionghoa sebagain besar berbentuk persegi panjang. b) Pada karakter bentuk atap, kuil di China menggunakan atap lengkung. Hal ini juga diterapkan pada kuil di Amerika dan Indonesia. Sedangkan pada bangunan ruko, tidak ada prinsip khusus yang harus diikuti, sehingga pada bentukan atap bangunan yang ada di China, Amerika dan Indonesia menyesuaikan dengan arsitektur lokal setempat.

c) Pada karakter warna, bangunan religius di China didominasi dengan warna merah dan kuning. Begitu juga dengan bangunan religius di Amerika, bangunan didominasi dengan warna merah dan kuning. Sedangkan pada bangunan religius di semarang, walaupun didominasi oleh warna merah ada warna-warna baru yang berbeda dari karakter warna Arsitektur Tionghoa pada umumnya, hal ini berkaitan dengan pengaruh budaya lokal.

d) Pada bangunan ruko, tidak ada aturan khusus dalam penggunaan warna. Namun warna merah sering digunakan pada beberapa ruko di China maupun Amerika. Sedangkan pada ruko di Semarang-Indonesia, warna ruko cenderung menyesuaikan dengan karakter arsitektur lokal. Perubahan warna ini berkaitan dengan makna warna merah yang menurut kepercayaan mereka membawa keberuntungan. Sedangkan warna yang menyesuaikan dengan karakter arsitektur lokal, dipengaruhi dengan ketersediaan bahan material di tempat tersebut dan pengaruh budaya yang kuat.

e) Pada karakteristik ornamen, perbandingan dikhususkan pada bangunan formal dan kuil (klenteng). Bangunan formal seperti bangunan istana pada pemerintahan menjadi penting berkaitan dengan kepercayaan masyarakat Tionghoa yang mengganggap pemimpinnya sebagai titisan dewa. Sedangkan kuil juga merupakan bangunan relegius tempat masyarakat Tionghoa beribadah. Pembahasan ornamen dibagi menjadi empat bagian yaitu toukung, kolom, sclupture dan pintu-jendela.

- Penggunaan Tou Kung pada atap bangunan di China menunjukkan ornamen dekoratif dan melambangkan sistem hirarki kekuasaan. Sedangkan pada detail ornamen Tou Kung di Amerika dan Indonsesia lebih sederhana dan hanya berfungsi sebagai elemen dekoratif. Hal ini berkaitan dengan fungsi hirarki kekuasaan menjadi sangat berpengaruh dalam tatanan pemerintahan di China, sedangkan diluar China bangunan relegius hanya berupa kuil yang tidak memiliki tingaktan kedudukan.

- Penggunaan kolom pada bangunan religius di China, Amerika dan Indonesia memiliki persamaan pada kolomnnya. Ketiga tempat memiliki kolom berbentuk silinder dengan ciri khas berwarna merah dengan ukiran dekoratif yang 
Hamdil Khaliesh. "Arsitektur Tradisional Tionghoa"

melambangkan kepercayaan.

Sedangkan kolom pada hunian di China tidak ada aturan khusus dalam perancangannya. Di China kolom ruko berbentuk persegi dengan hiasan ukiran Tionghoa, di Vancouver kolom ruko mengadopsi kolom doric Yunani dan di Semarang kolom ruko berbentuk persegi dengan hiasan ukiran kolonial.
- Pada sclupture bangunan religius di China, Amerika dan Indonesia memiliki persamaan. Patung hewan digunakan sebagai kepercayaan supranatural.

- Pada detail pintu-jendela bangunan ruko di China, Amerika dan Indonesia tidak ada yang sama. Masing-masing negara menyesuaikan dengan gaya arsitektur setempat.

Tabel 1: Analisis Persamaan dan Perbedaan Karakteristik Arsitektur Tionghoa

Di Negara China, Amerika dan Indonesia
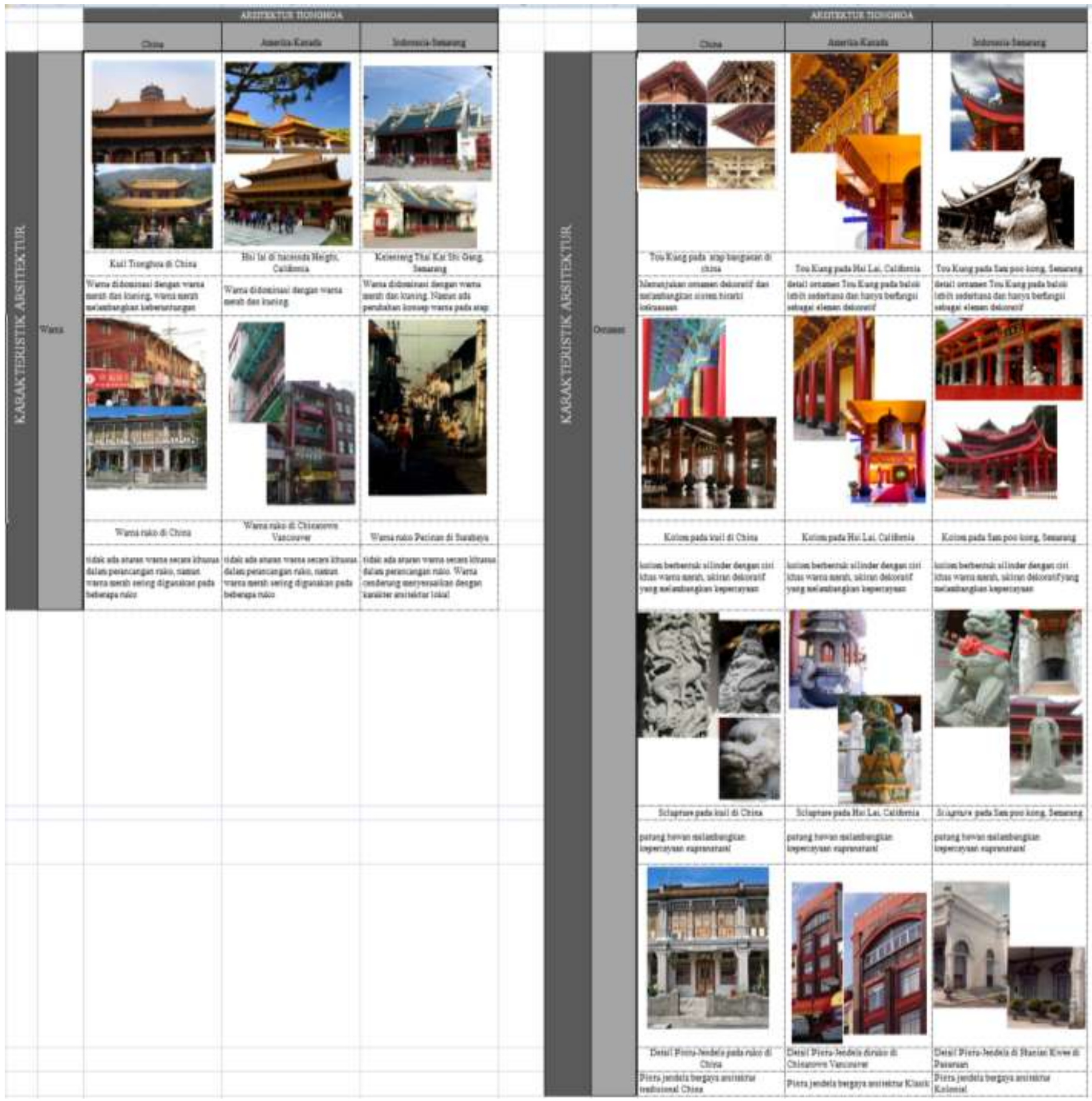

Sumber: Penulis, 2014 
Tabel 1: Analisis Persamaan dan Perbedaan Karakteristik Arsitektur Tionghoa

Di Negara China, Amerika dan Indonesia (lanjutan)
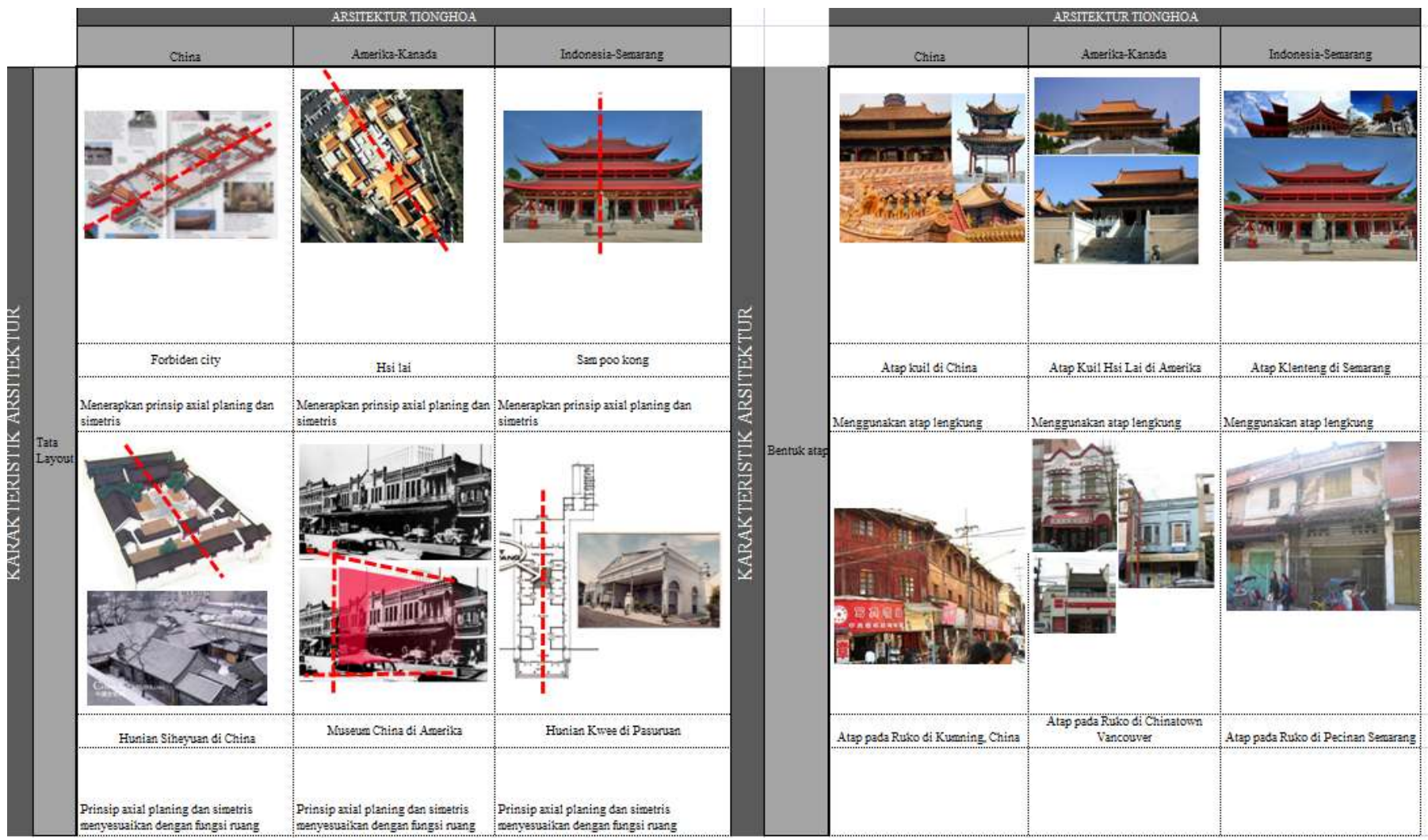

Sumber: Penulis, 2014

\section{Kesimpulan}

Dari pembahasan di atas, dapat disimpulkan bahwa Arsitektur Tionghoa sangat berkaitan dengan budaya masyarakatnya. Sedangkan pengetahuan dasar budaya masyarakat fionghoa itu sendiri sangat berkaitan dengan unsur kepercayaan pada ajaran leluhur mereka. Sehingga dapat dimengerti bahwa identitas arsitektur yang paling menonjol ada pada bangunan-bangunan relegius. Sedangkan pada bangunan-bangunan rumah tinggal dan ruko, tidak terlalu terlihat karena beradaptasi dengan fungsi bangunan, walaupun pada prinsipnya kepercayaan tetap digunakan sebagai prinsip perancangan.

Perbedaan mendasar tersebut karena Bangunan rumah tinggal atau ruko adalah bangunan privat dengan tingkat kebutuhan ruang yang berbeda untuk tiap unitnya. Berbeda dengan bangunan religius yang secara prinsip kebutuhan ruangnya sama, perbedaan hanya pada bentuk lansekap dan lingkungannya saja. Hal ini terbukti dengan tampilan fisik pada bangunan religius di China, Amerika dan Indonesia cenderung sama. Sedangkan, pada bangunan hunian atau ruko tampilan fisik bangunannya cenderung mengikuti dengan arsitektur lokal setempat.

Dari hasil perbandingan, ciri khas khusus yang memiliki kemiripan antara bangunan arsitektur di Amerika, Indonesia dan negara asalnya "China" adalah bentuk atau layout bangunan yang simetris, axial planning dengan konsep courtyard, karakteristik warna didominasi warna merah dan kuning , bentuk atap melengkung pada ujungnya dan memiliki ornamen arsitektural yang berkaitan dengan kepercayaan. Karakteristikkarakteristik tersebut berhubungan erat dengan prinsip kepercayaan masyarakat Tionghoa terhadap leluhur mereka. Sehingga dapat disimpullkan:

- Persamaan karakteristik Arsitektur tradisional Tionghoa di berbagai tempat menggambarkan tingkat eksistensi identitas Arsitektur Tionghoa masih tetap terjaga

- Faktor yang paling berpengaruh terhadap tingkat eksistensi identitas Arsitektur tradisional Tionghoa adalah kepercayaan.

- Kepercayaan masyarakat Tionghoa pada ajaran leluhurnya jugalah yang menjadi faktor utama eksistensi budaya masyarakat Tionghoa di berbagai tempat.

\section{Referensi}

Banks, J.A., Banks, \& McGee, C. A. 1989. Multicultural education. Needham Heights, MA: Allyn \& Bacon.

Carey, Peter. 1985. Masyarakat Jawa dan Masyarakat China. Jakarta: Pustaka Azet

Catanese, A. J. \& Snyder, J. C. (1991). Pengantar Arsitektur. Jakarta: Penerbit Erlangga 
Chen, Joyce. 2011. Chinese Immigration to the United States:History, Selectivity and Human Capital. The Ohio State University.

Damen, L. 1987. Culture Learning: The Fifth Dimension on the Language Classroom. Reading, MA: AddisonWesley.

García. J. F. Culture. Ashland University, Ohio.

http://personal.ashland.edu/jgarcia/cult ure1.html, didownload pada 15 okteober 2011.

Guo, Shibao \& Don J. DeVoretz. 2006. Chinese Immigrants in Vancouver: Quo Vadis? Discussion Paper No. 2340. Simon Fraser University. Burnaby, BC V5A 1S6. Canada

Handinoto. $2008 . \quad$ Perkembangan Bangunan Etnis Tionghoa di Indonesia (Akhir Abad ke 19 sampai tahun 1960-an). (Prosiding Simposium Nasional Arsitektur Vernakular 2. Petra Christian University - Surabaya

Khol, David G. 1984. Chinese Architecture in The Straits Settlements and Western Malaya: Temples Kongsis and Houses, Heineman Asia, Kuala Lumpur. Archipel. Volume 33, 1987. p. 185

Kupier, Kathleem. 2011. The Culture Of Tionghoa. Britannica Educational Publishing. New York

Maspero, Henri. Translated by Frank A. Kierman, Jr. 1981. Taoism and Chinese Religion. University of Massachusetts

O'Gorman, J. F. 1997. ABC of Architecture. Philadelphia: University of Pennsylvania Press
Pratiwo. 2010. Arsitektur Tradisional

Tionghoa dan Perkembangan Kota.

Penerbit Ombak. Yogyakarta

Rummens, Joanna. 2001. An Interdisciplinary Overview of canadian Research on Identity. Department of Canadian Heritage for the Ethnocultural, Racial, Religious, and Linguistic Diversity and Identity Seminar Halifax, Nova Scotia

Salem, MA. A Teacher's Sourcebook for Chinese Art \& Culture. Peabody Essex Museum.

Guo, Shibao and Don J. DeVoretz. 2006. Chinese Immigrants in Vancouver:Quo Vadis? IZA Discussion Paper. Germany

Taylor, Rodney L. 1982. "Proposition and Praxis: The Dilemma of NeoConfucian Syncretism". Philosophy of East and West, Vol. 32, No. 2 pg. 187

Wade, Geoff. 2007. The “Liu/Menzies”World Map: A Critique. e-Perimetron, Vol. 2, No. 4, Autumn 2007 [273-280]

Widayati, Naniek. 2004. Telaah Arsitektur Berlanggam China di Jalan Pejagalan Raya Nomor 62 Jakarta Barat. Dimensi Teknik Arsitektur Vol. 32, No. 1, Juli 2004: 42 - 56

Wigglesworth, S. \& Till, J. 1998. The Everyday and Architecture. Architectural Design. New York: Princeton Architectural Press

Wong, Bernard. 1998. Ethnicity and Entrepreneurship: The New Chinese Immigrants in the San Francisco Bay Area. Allyn \&Bacon A Simon \& Schuster Company. San Francisco State University. United States of America 